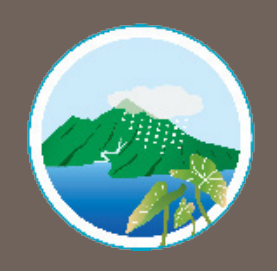

University of Hawai'i Water Resources Research Center

UNIVERSITY OF HAWAI'I AT MĀNOA

\title{
Water Quality Impacts of Fertilizers in American Samoa
}

A review of existing water quality studies and data that show how nutrients from sources including fertilizers may impact coastal and inland waters

Christopher K. Shuler* and Michael Mezzacapo

*Corresponding author: cshuler@hawaii.edu

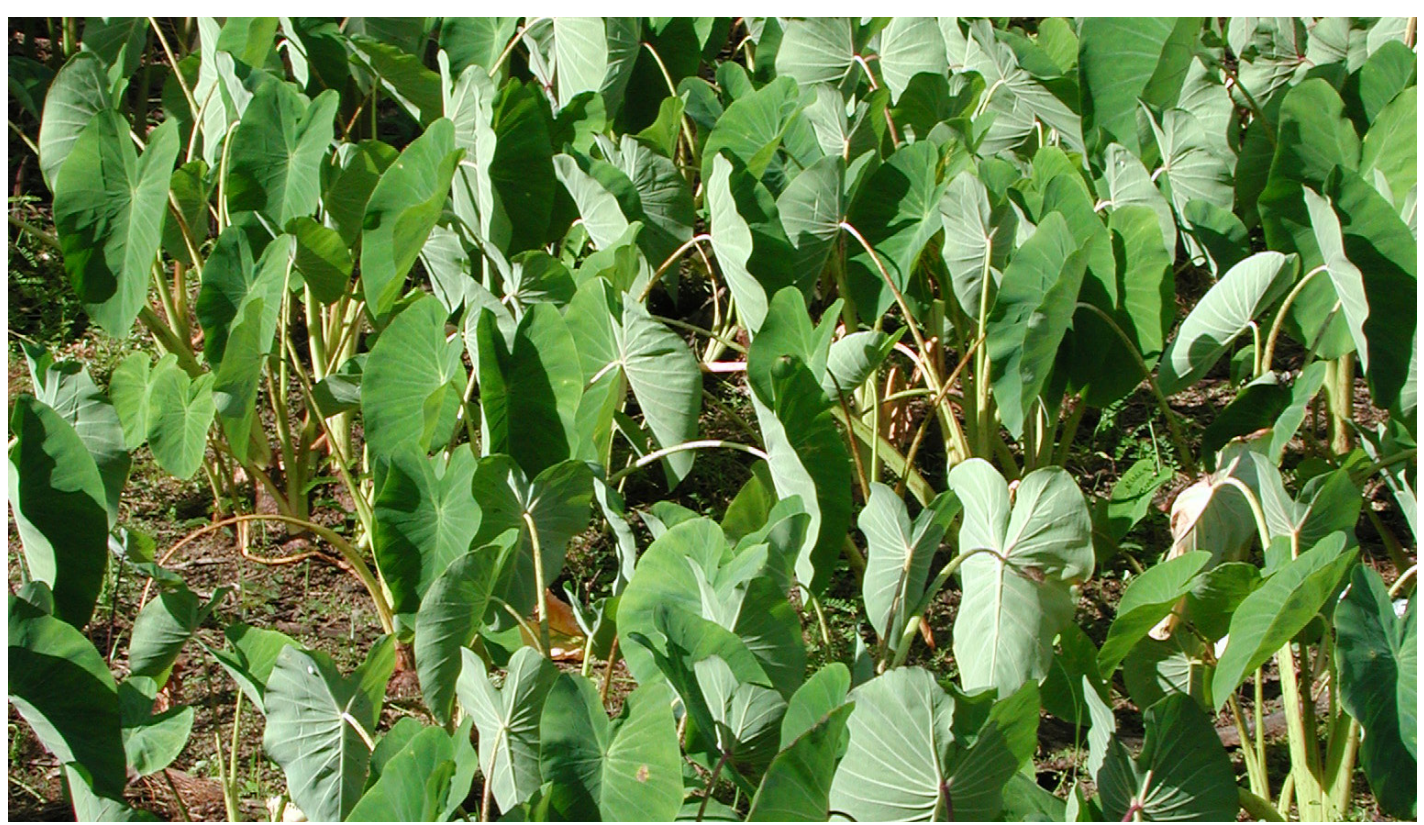




\section{Summary of Findings}

\section{THE STUDIES REVIEWED HERE SUGGEST SYNTHETIC FERTILIZERS ARE NOT A PREDOMINANT OR CONCERNING SOURCE OF NUTRIENTS TO THE ENVIRONMENT.}

A majority of the studies reviewed in this policy brief found instances of moderately elevated levels of nutrient discharge (relative to control sites) to Tutuila's streams and coastal waters in inhabited areas. Nitrogen $(\mathrm{N})$ levels in streams and groundwater sometimes exceed American Samoa's fresh surface water quality standards, and infrequently exceed the American Samoa coastal water quality standards (ASEPA, 2013). However, results from studies that applied source tracing methods clearly indicate human wastewater from cesspools and poorly located septic tanks is the major source of nitrogen to environmental waters. Manure from piggeries is often found to be the second most important source, whereas the impact from imported synthetic fertilizers has been found to be fairly low, on the same order of magnitude as natural levels of nitrogen discharge to pristine coastlines.

\section{Other relevant findings:}

- Relatively high-levels of phosphorus $(P)$ in groundwater and streams discharging to the coast is likely from natural sources such as bird guano or weathering of basalt.

- A single fertilizer related algal bloom has been documented in the territory. This event was related to "aggressive" fertilization at the soccer field directly on the harbor, with fast draining soils and no runoff control.

\section{Indicators of Impact}

Nitrogen Concentrations and Nitrogen Isotopes $\left(\delta^{15} \mathrm{~N}\right)$ in Water and Biotic Samples are Key for Assessing the Sources of Nutrient Pollution and their Impacts on the Environment.

Nitrogen Concentrations: The amount of nitrogen contained in land-based and coastal waters directly affects the health of sensitive reef ecosystems. Excess nitrogen concentrations can cause reef smothering or toxic algal blooms. Nitrogen can come in different forms, typically waters are tested for total nitrogen (TN) or inorganic nitrogen, with the most common form being nitrate $\left(\mathrm{NO}_{3}^{-}\right)$. Water quality standards set by regulatory agencies provide baseline and comparative values for water quality tests. The 2013 AS WQ standards have a TN limit for fresh surface waters of $0.3 \mathrm{mg} / \mathrm{L}$ (median value) and for coastal waters in bays the limit is $0.15 \mathrm{mg} / \mathrm{L} \mathrm{TN}$ (median). Hawaii State Water Quality Standards (HAR Chapter 11-54) set limits in streamwater for TN at $0.25 \mathrm{mg} / \mathrm{L}^{2}$ and for $\mathrm{NO}_{3}$ at $0.07 \mathrm{mg} / \mathrm{L}$. The U.S. EPA drinking water standard for $\mathrm{NO}_{3}$ is $10.0 \mathrm{mg} / \mathrm{L}$.

Table 1: Concentrations of $\mathrm{NO}_{3}^{-}$in coastal-draining streams and springs from studies conducted in American Samoa and $n$ H Hawall, for context. Note: see concentration Note that in AS strens and and Hawa Note that in $\mathrm{AS}$ streams and groundwater, $\mathrm{NO}_{3}$ is often the main form of $\mathrm{N}$ in $\mathrm{TN}$.

\begin{tabular}{|c|c|c|c|c|c|}
\hline Data Source & $\begin{array}{c}\text { Median } \\
\text { No } \\
(\mathrm{mg} / \mathrm{L})\end{array}$ & $\begin{array}{l}\text { Average } \\
\text { No } \\
(\mathrm{mg} / \mathrm{L})\end{array}$ & $\begin{array}{c}\text { Max } \\
\text { No3 } \\
(\mathrm{mg} / \mathrm{L})\end{array}$ & $\begin{array}{l}\text { Number } \\
\text { of } \\
\text { samples }\end{array}$ & Type(s) of samples \\
\hline \begin{tabular}{|l} 
Comeros-Raynal et al. \\
(2020) (Tutuila)
\end{tabular} & 0.05 & 0.09 & 1.33 & 466 & $\begin{array}{l}\text { Streams and coastal } \\
\text { springs, islandwide }\end{array}$ \\
\hline $\begin{array}{l}\text { Shuler et al. (2019a) } \\
\text { (Tutuila) }\end{array}$ & 0.16 & 0.23 & 1.1 & 23 & $\begin{array}{l}\begin{array}{l}\text { Streams, coastal } \\
\text { springs, } 4 \text { sites }\end{array}\end{array}$ \\
\hline $\begin{array}{l}\text { Shuler et al. (2019b) } \\
\text { (Tutuila) }\end{array}$ & 0.11 & 0.22 & 0.93 & 11 & $\begin{array}{l}\text { Streams and coastal } \\
\text { springs, Fagaalu }\end{array}$ \\
\hline $\begin{array}{l}\begin{array}{l}\text { Shuler et al. (2017) } \\
\text { (Tutuila) }\end{array} \\
\text { (a) }\end{array}$ & 0.86 & 0.90 & 1.81 & 35 & Wells, Tafuna-Leone \\
\hline \multicolumn{6}{|c|}{ ASPA groundwater monitoring data (Nov 2008 to Oct 2019) } \\
\hline Wells in Western Tutuila & 0.65 & 0.65 & 1.50 & 19 & Production Wells \\
\hline Wells in Central Tutuila & 0.15 & 0.16 & 0.61 & 91 & Production Wells \\
\hline Wells in Eastern Tutuila & 0.17 & 0.17 & 0.36 & 80 & Production Wells \\
\hline \begin{tabular}{|l} 
Wells in Tafuna Leone \\
Plain Region
\end{tabular} & 0.90 & 0.91 & 2.10 & 292 & Production Wells \\
\hline \multicolumn{6}{|c|}{ Comparison to Hawaii studies } \\
\hline 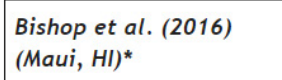 & $\cdot$ & 1.52 & 5.3 & 50 & \begin{tabular}{|l|} 
Coastal Springs, 6 \\
different locations
\end{tabular} \\
\hline $\begin{array}{l}\text { Wiegner and Mead } \\
(2009),(\text { Hilo, HI)* }\end{array}$ & - & 0.37 & 0.52 & 12 & $\begin{array}{l}\text { Wailoa river, Hilo } \\
\text { Bay }\end{array}$ \\
\hline
\end{tabular}

Nitrogen Isotopes: ${ }^{15} \mathrm{~N}$ is a rare isotope of nitrogen $(\mathrm{N})$, most of which is in the form of ${ }^{14} \mathrm{~N}$. The ratio between these two isotopes relates to the $\delta^{15} \mathrm{~N}$ value, and this value changes when $\mathrm{N}$ is produced by different sources. Specifically, manure and wastewater produce elevated $\delta^{15} \mathrm{~N}$ values between $5 \%$ and $25 \%$ and synthetic fertilizers produce $\delta^{15} \mathrm{~N}$ values centered around $0 \%$ (Figure 1). Natural processes in soils produce $\mathrm{N}$ with $8^{15 \mathrm{~N}}$ values between $4 \%$ and $6 \%$. Therefore when water or biologic samples show high $\delta^{15} \mathrm{~N}$ values (greater than $7 \%$ - 10\%) this indicates the $\mathrm{N}$ found in the sample likely came from a wastewater source. When samples show low $\delta^{15} \mathrm{~N}$ values (near $0 \%$ ) it suggests the $\mathrm{N}$ came from synthetic agricultural fertilizers.

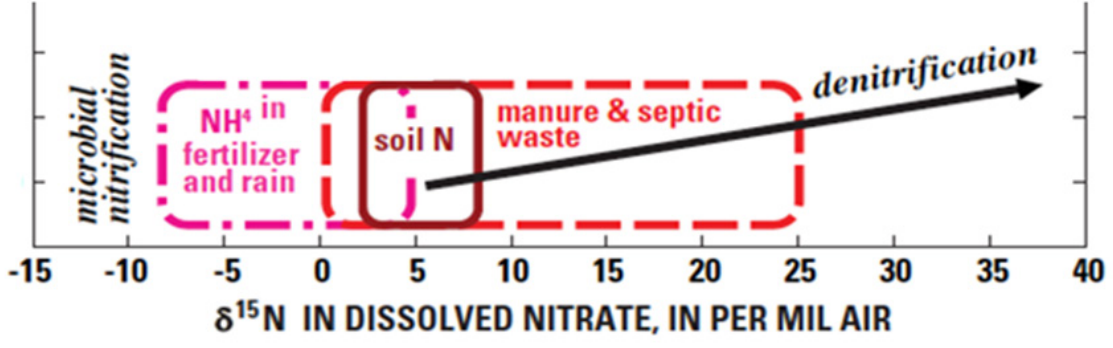

Figure 1: Graph showing classification of nitrogen sources based on nitrogen isotope compositions of dissolved nitrate (modified from Kendall and McDonnell, 1998).
The Water Resources Research Center (WRRC) is a research WRRC has worked with agencies in American Samoa institute at the University of Hawai'i at Mānoa dedicated since 2013 to develop an integrated water resources reto promote understanding of critical state and regional search program to address territorial concerns. Multiple (including the U.S. Affiliated Pacific Islands) water resource WRRC studies examining nutrient impacts have resulted management and policy issues through applied research, in peer-reviewed journal articles and reports relating to community outreach, and public education. the effects of nutrients in coastal and inland waters. 


\section{Summaries of Relevant Studies}

SHULER ET AL. (2017). SOURCE PARTITIONING OF ANTHROPOGENIC GROUNDWATER NITROGEN IN A MIXED USE LANDSCAPE, TUTUILA, AMERICAN SAMOA

Key Finding: On the Tafuna-Leone Plain, only $9 \%$ of nitrogen in groundwater was estimated to come from synthetic fertilizers, however, $60 \%$ came from cesspools or septic tanks.

Water samples were collected from drinking water wells across Tutuila and combined the water quality data with a groundwater model to determine which land use activities contribute the most nitrogen to the groundwater. The model accounted for nitrogen contributions from cesspools, piggeries, agriculture, and natural sources, and found that on the Tafuna-Leone Plain, $60 \pm$ $7 \%$ of the nitrogen in groundwater was from cesspools, $20 \pm 6 \%$ was from piggeries, $12 \pm 1 \%$ was from natural sources, and only $9 \pm 4 \%$ was sourced from agricultural application of synthetic fertilizers. The model results were independently validated with $\delta^{15} \mathrm{~N}$ values, which are a source-dependent tracer that can identify the difference between nitrogen from synthetic fertilizers and nitrogen from wastewater or manure.

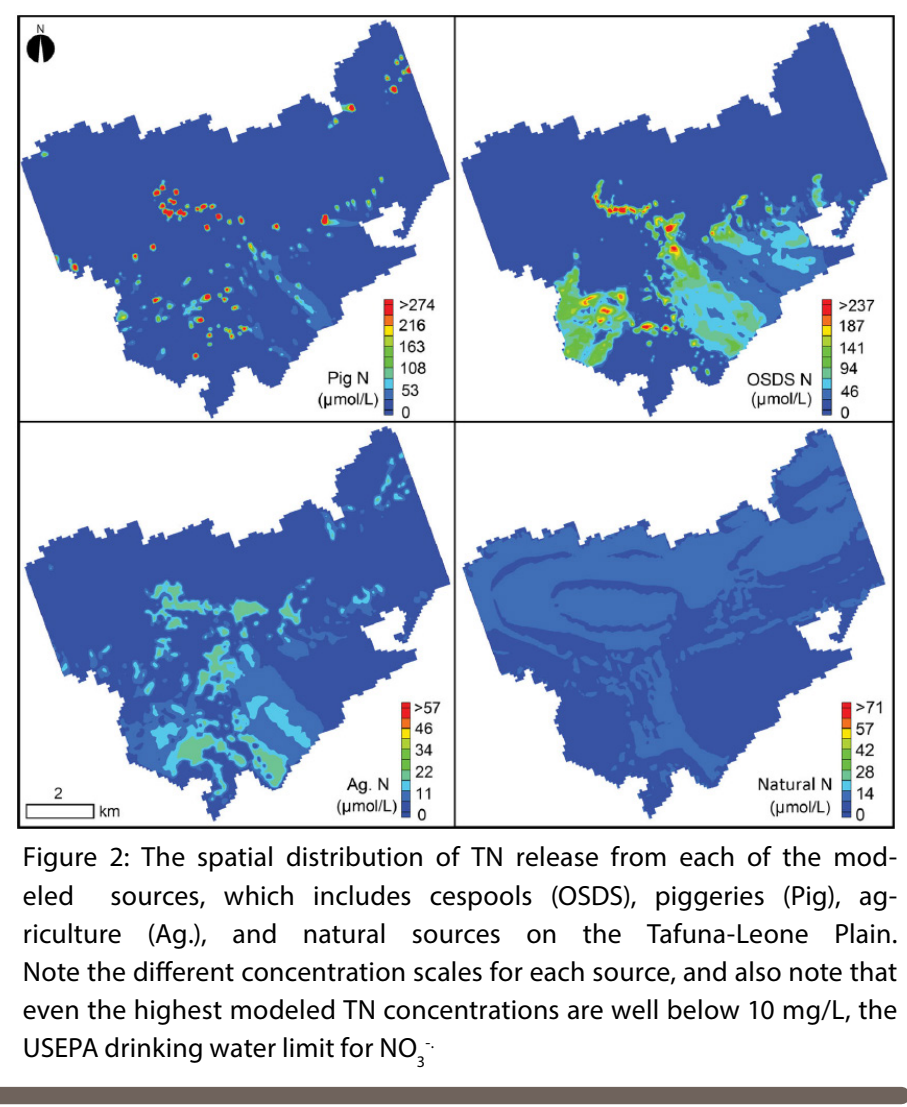

WELCH ET AL. (2019). SUBMARINE GROUNDWATER DISCHARGE AND STREAM BASEFLOW SUSTAIN PESTICIDE AND NUTRIENT FLUXES IN FAGA'ALU BAY, AMERICAN SAMOA

Key Finding: A groundwater model was used to estimate that $90 \%$ of the dissolved nitrogen entering coastal waters come from cesspools and septic tanks.

Groundwater and surface water samples were taken at 13 sites throughout Fagaalu Watershed, and analyzed for nutrients ( $\mathrm{N}$ and $\mathrm{P}$ ), glyphosate (Roundup ${ }^{\circ}$ ), and 3 pesticides (DDT, imidacloprid, and azoxystrobin). Results showed all samples had detectable levels of glyphosate, averaging $160 \pm 80 \mathrm{ng} / \mathrm{L}$. This concentration is nearly 3,000 times below the EPA drinking water limit for glyphosate of 700,000 ng/L. The legacy pesticide DDT was detected at most sites, while the other two pesticides were not detected at any sites.
SHULER ET AL. (2019B). UNDERSTANDING SURFACE WATER-GROUNDWATER INTERACTION, SUBMARINE GROUNDWATER DISCHARGE, AND ASSOCIATED NUTRIENT LOADING IN A SMALL TROPICAL ISLAND WATERSHED

Key Finding: Isotope analysis of water in Fagaalu Stream suggests excess nitrogen originates from wastewater sources.

Surface water samples were collected during a survey through Fagaalu Stream, and also took coastal water samples on the reef flat. Samples were analyzed for nutrients and $\delta^{15} \mathrm{~N}$ values of dissolved inorganic nitrogen. Results showed $\delta^{15} \mathrm{~N}$ values increased downstream. This corresponded to an increase in human impact on the stream, suggesting that as the stream flows through the village, delivery of excess nitrogen is primarily due to either wastewater or manure, and not agricultural inputs.

SHULER ET AL. (2019A). ASSESSMENT OF TERRIGENOUS NUTRIENT LOADING TO COASTAL ECOSYSTEMS ALONG A HUMAN LAND-USE GRADIENT, TUTUILA, AMERICAN SAMOA

Key Finding: Nitrogen isotopes in water and algae show excess nitrogen in stream and spring water is from a wastewater source rather than an agricultural source.
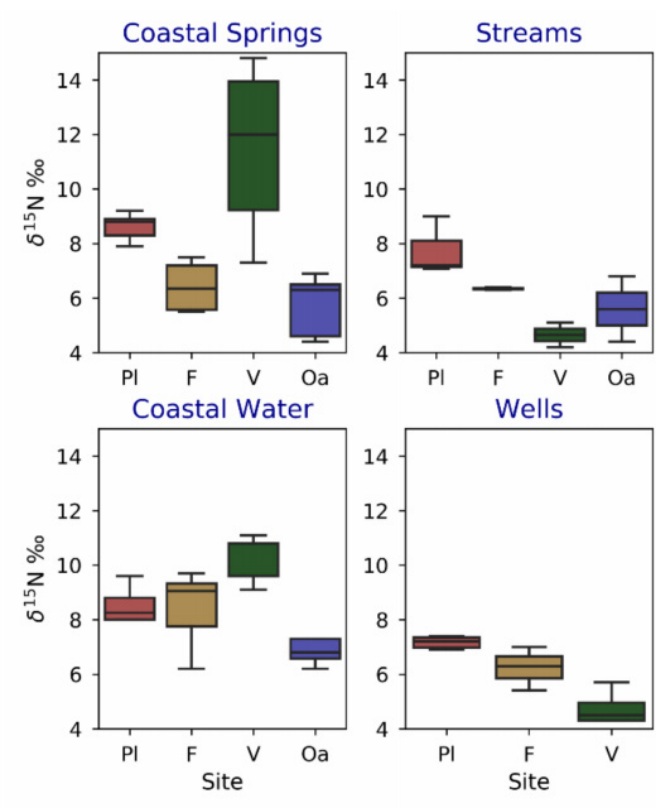

Coastal water quality was examined in four of Tutuila's watersheds and reef flats. Water samples were taken from coastal groundwater, streams, and nearshore surface water. Samples were analyzed for nutrient concentrations and $\delta^{15} \mathrm{~N}$ values of dissolved inorganic nitrogen. Tissue samples of macroalgae (seaweed) were also taken from reef flats to test for the origin of their $\mathrm{N}$ using $\delta^{15} \mathrm{~N}$ values. The $\delta^{15} \mathrm{~N}$ values of dissolved inorganic nitrogen can 'fingerprint' the sources of $\mathrm{N}$ in water and algae samples. In all human impacted study sites, both water and algae samples showed elevated $\delta^{15} \mathrm{~N}$ values (relative to the pristine site) indicating excess nitroge found in stream and spring water can be traced to a wastewater source rather than an agricultural source. Additionally, phosphate concentrations in Tutuila's coastal waters were found to be unusuFigure 3: Results of water quality samples analyzed for $\delta^{15} \mathrm{~N}$ ally high, even at the pristine site. This indicated natural sources from four bays across Tutuila. Box center lines represent median, edges represent interquartile range, and whiskers represent range. Site names are coded as, Pala Lagoon: Pl, Faga'alu: $F$, Vatia: $V$, and Oa: Oa. The PL site is heavily im pacted by human land-use, the F and sites are moderate- al high even at the pistine site. This indicad natral sour of phosphorus such as dissolution from basalt or perhaps seabird guano create a naturally high $\mathrm{P}$ environment in Tutuila's coasta waters, which is not surprising considering similar results from other basaltic islands. 


\section{Summaries of Relevant Studies (continued)}

MORTON ET AL. (2011). COASTAL EUTROPHICATION, LAND USE CHANGES AND CERATIUM FURCA (DINOPHYCEAE) BLOOMS IN PAGO PAGO HARBOR, AMERICAN SAMOA 2007-2009

Key Finding: Excessive fertilization of the Pago Soccer Field caused a red-tide algal bloom in the harbor. This event was isolated and quickly mitigated.

This study covers the only scientifically documented example of an algal bloom in Pago Pago Harbor. The first stage of the red-tide algal bloom (composed of dinoflagellates) was thought to have been caused by application of $1,000 \mathrm{~kg}$ of fertilizer over 6 months at a site directly adjacent to the most enclosed part of Pago Pago Harbor with no natural buffer or effective run-off management practices. An algal bloom of this scope had not been observed before this event and has not been observed since. This work describbes the only known instance of environmental impacts caused by fertilizer on Tutuila, and this was an isolated event which was rapidly mitigated through better runoff management and best practices.

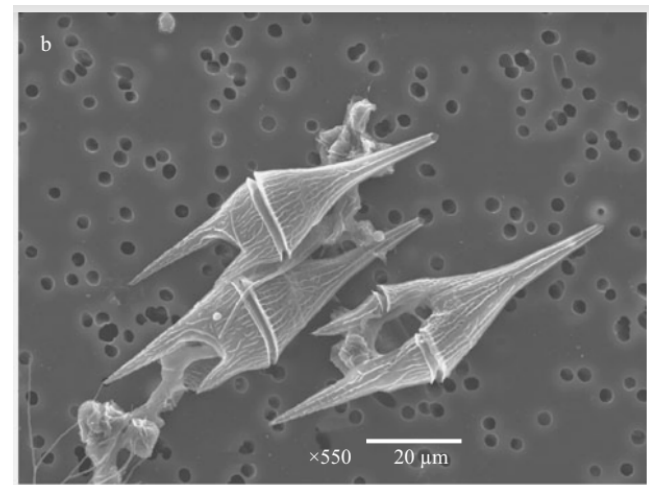

Figure 4: Scanning electron micrograph of Ceratium furca. Adapted from Morton et al. 2011.
WHITALL AND HOLST (2015). POLLUTION IN SURFACE SEDIMENTS IN FAGA'ALU BAY, TUTUILA, AMERICAN SAMOA

Key Finding: Contamination in Fagaalu from organics and heavy metals was generally low with a few exceptions. Levels of N \& P in coastal waters were within AS water quality standards.

Sediments sampled in Fagaalu Stream and Bay were tested for polycyclic aromatic hydrocarbons (PAHs), polychlorinated biphenyls (PCBs), pesticides, and heavy metals. 'Snapshot' measurements of dissolved nitrogen and phosphorus were also taken from coastal water in Fagaalu Bay, and levels were found to be within AS and Hawaii water quality standards. In general, pollution in Faga'alu Bay sediments and watershed streams was low. Some contaminants were found at elevated or potentially concerning levels including: arsenic, chromium, nickel, silver, zinc, chlordane, DDT, and PCBs. Contaminants like nickel, silver, and zinc may be elevated due to natural geologic erosion or exacerbated by mining activities at a nearby quarry. It was also hypothesized that a legacy landfill beneath the elementary school may be a potential source of pollution, though future research is needed.
COMEROS-RAYNAL ET AL. (2020). IMPROVING WATERSHED AND ISLAND SCALE RESILIENCE THROUGH A QUANTITATIVE PRIORITY-SETTING MANAGEMENT FRAMEWORK

Key Finding: Island-wide, monthly water sampling data and a nitrogen loading model was used to determine that only $3-5 \%$ of coastal nitrogen discharge comes from agriculture.

Dissolved inorganic nitrogen (DIN) concentrations were measured monthly in streams and reefs for a year at 20 sites across the island. Statistical analysis of the 466 stream and spring samples showed moderately elevated concentrations of DIN in some villages (Table 1). These data were used to develop a whole island nitrogen loading model which was able to link and quantify coastal DIN discharge from human and natural sources. The model indicated the vast majority of DIN being discharged to reefs comes from cesspools, with piggeries being a secondary source. Agricultural fertilizers were estimated to be responsible for $3 \%$ to $5 \%$ of the DIN discharged to coastal waters. This work was conducted collaboratively by AS-EPA, CRAG, Marine Sanctuaries, and UH-WRRC.

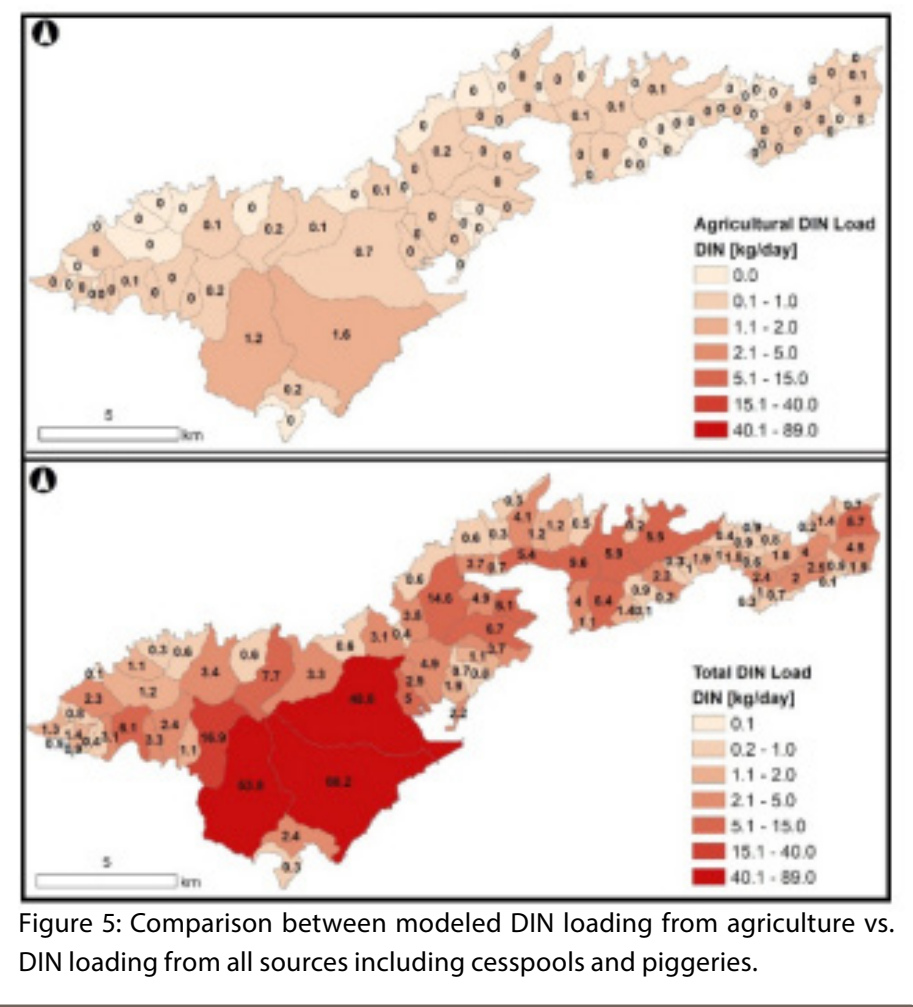

WHITALL ET AL. (2019). EXCESS NUTRIENTS IN VATIA BAY, AMERICAN SAMOA: SPATIOTEMPORAL VARIABILITY, SOURCE IDENTIFICATION AND IMPACT ON CORAL REEF ECOSYSTEMS

Key Finding: Nitrogen pollution is a problem in Vatia Bay. Most $\mathrm{N}$ is likely from wastewater, as there is only limited agriculture in the watershed, and wastewater indicators were found.

Table 2. Estimated nitrogen budget for Vatia
Bay. Adapted from Whitall et al. (2019).
\begin{tabular}{|l|c|c|}
\hline $\begin{array}{c}\text { Nitrogen } \\
\text { Source }\end{array}$ & $\begin{array}{c}\text { Total N Load } \\
\text { to Bay (kg) }\end{array}$ & $\begin{array}{c}\% \text { of Load } \\
\text { from Source }\end{array}$ \\
\hline Wastewater & 3,200 & $43 \%$ \\
\hline Pigs & 3,016 & $40 \%$ \\
\hline Dogs & 600 & $8 \%$ \\
\hline Agriculture & 200 & $3 \%$ \\
\hline Forest & 486 & $6 \%$ \\
\hline Total & 6,118 & $100 \%$ \\
\hline
\end{tabular}

Coastal water was sampled at 17 sites in Vatia Bay for nutrients and wastewater indicators (sucralose, and caffeine). Results indicate nutrient pollution, especially nitrogen, is a problem in Vatia Bay. The presence of sucralose and caffeine tracers also show that human waste is reaching the bay. The authors note that crop agriculture is not prevalent in the watershed. Therefore, fertilizer input is unlikely to be a significant source of nitrogen pollution. 


\section{References}

Bishop, J. M., Glenn, C. R., Amato, D. W., \& Dulai, H. (2016). Effect of land use and groundwater flow path on submarine groundwater discharge nutrient flux. Journal of Hydrology: Regional Studies, 11, 194-218. https://doi.org/10.1016/.j.jh. 2015.10.008

Comeros-Raynal, M.T., Shuler, C.K., Regis, J, Sudek, M., Coward, G., Lawrence, A. (2019). Improving watershed and island scale resilience through a quantitative priority-setting management framework. Project completion report US EPA Wet-land Program. American Samoa EPA, Pago Pago, AS. 51 p.

Morton, S. L, Shuler, A, Paternoster, J., Fanolua, S., \& Vargo, D. (2011). Coastal eutrophication, land use changes and Ceratium furca (Dinophyceae) blooms in Pago Pago Harbor, American Samoa 2007-2009. Chinese Journal of Oceanology and Limnology, 29(4), 790-794. https://doi.org/10.1007/500343-011-0507-7

Shuler, C. K., Amato, D. W., Gibson, V., Baker, L, Olguin, A. N., Dulai, H.,...\& \& Alegado, R. A. (2019a). Assessment of terrigenous nutrient loading to coastal ecosystems along a human land-use gradient, Tutuila, American Samoa. Hydrology, 6(1), 18. https://doi org/10.3390/hydrology 6010018

Shuler, C. K., Dulai, H., Leta, O. T., Fackrell, J., Welch, E., \& El-Kadi, A. I. (2019b). Understanding surface water-groundwater interaction, submarine groundwater discharge and associated nutrient loading in a small tropical island watershed. Journal of Hydrology, 124342. https://doi.org/10.1016/j.jhydrol.2019.124342

Shuler, C. K., E-Kadi, A. ., Dulai, H., Glenn, C. R., \& Fackrell, J. (2017). Source partitioning of anthropogenic groundwater nitrogen in a mixed-use landscape, Tutuila, America

Welch, E. M., Dulai, H., El-Kadi, A., \& Shuler, C. (2019). Submarine groundwater discharge and stream baseflow sustain pesticide and nutrient fluxes in Faga'al Bay, American Samoa. Frontiers in Environmental Science, 7, 162. https://doi.

Whitall, D., M. Curtis, A. Mason, and B. Vargas-Angel. 2019. Excess Nutrients in Vatia Bay, American Samoa: Spatiotemporal Variability, Source Identification and Impact on Coral Reef Ecosystems. NOAA Technical Memorand

Whitall, D., and S. Holst. 2015. Pollution in Surface Sediments in Faga'alu Bay, Tutuila, American Samoa. NOAA Technical Memorandum NOS NCCOS 201. Silver Spring, MD. 54 pp. hetps.//Lo.

Wiegner, T. N. \& Mead, L. (2009). Water quality in Hilo Bay, Hawaii, USA, under
baseflow and storm conditions. Professional report to Hawaii County's Department of Public Works, Engineering Division, Hilo, HII.

\section{Author's Note:}

This version of the policy brief was modified from a more in-depth versiondetailing the effects of fertilizers and other agricultural impacts in American 